\title{
Obituary
}

\section{HAROLD RICHARD DENHAM}

1917-1999

Harold Denham, who died aged 81 on 19 January, was Chief Cataloguer in the Wellcome Library from 1951 to 1982 and earned the gratitude of medical historians and bibliographers by his meticulous editorial work on the Library's Catalogue of printed books.

Born in Portsmouth on 8 April 1917, he was educated at Portsmouth Grammar School and in 1937 joined the staff of Watford Public Library. In 1940 he was conscripted into the Royal Corps of Signals and trained as a telephonist, but spent most of his service as a prisoner-of-war in Singapore. After the War he returned to Watford, qualified as ALA in 1948, and moved in 1950 to the Royal College of Physicians, then still in Pall Mall East. He was recruited to the Wellcome Library in April 1951 for a catalogue revision project specially funded by the Wellcome Trust, following an interview at which the then Director, Dr Underwood, showed less interest in his cataloguing skills than in his estimated rate of output. His appointment was, incidentally, the first step in the rebuilding of the library staff following the cuts of 1948 , in which his predecessor had been made redundant.

Throughout the 1950s he trained and led a team of cataloguers working under the less-than-ideal conditions of the Library in its makeshift state before the 1962 refurbishment. The Cataloguing Room was then in the south east corner of the Reading Room and was shared with the typists, who spent much of their time gossiping and making tea. The revision project was concluded in the early 1960 s with a complex retyping and interfiling of a variety of slips and cards, some handwritten, to produce an integrated card catalogue.

Harold Denham's involvement with the Catalogue of printed books began in 1957. Work on the proofs of Volume I (pre-1641) had been started in 1954, under Noël Poynter's supervision, and some features might have been different had Harold Denham been involved from the start. Apart from careful proof-reading, he compiled the indexes, and the volume was generally acclaimed on its appearance in 1962. Volume II (1641-1850 A-E) followed in 1966, completed under extreme pressure to an over-optimistic deadline. He was allowed a freer hand with Volume III (F-L), 1976, the first to carry his name on the title-page, and by his retirement in 1982 he had commenced work on Volume IV (M-R), though it was not completed until 1995. The series owes its reputation as a bibliographical reference work to his unerring eye and painstaking attention to detail, although his innate modesty and unassuming manner often caused his achievement to be underestimated.

Cataloguing occupied most of his time-indeed in the 1950s the Wellcome Trustees required assurance that the cataloguers whom they were funding were not being diverted to other library tasks. He did, however, often provide bibliographical assistance in the way of indexing and reference-checking, notably to Kenneth Keele and Carlo Pedretti's monumental edition of Leonardo da Vinci's anatomical drawings and to J M Tanner's History of the study of human growth. His plans for a bibliography of Thomas Willis as an FLA thesis were thwarted by the Library Association's bureaucracy, but he was able to include much of his material in the elegant tercentenary edition of Willis's The anatomy of the brain and nerves published by McGill University in 1965 . Following a holiday in Norway he experimented at translating Norwegian medical histories into English.

He enjoyed a long and happy home life with his wife Jean and their children, Sarah, Nicola and Matthew and, eventually, grandchildren. He and Jean showed great determination in resisting the limitations of increasing ill health and her death in 1998 was a blow from which he never really recovered. He will be much missed.

John Symons 